\title{
Manuscripts Reviewed for the 2014 Yearbook
}

Abrahamsson N, Engström BE, Sundbom M, Karlsson FA. GLP1 analogs as treatment of postprandial hypoglycemia following gastric bypass surgery: a potential new indication? Eur J Endocrinol 2013; 169: 885-89 page $\mathrm{S}-122$

Ackermann RT, Sandy LG, Beauregard T, Coblitz M, Norton KL, Vojta D. A randomized comparative effectiveness trial of using cable television to deliver diabetes prevention programming. Obesity 2014; 22: 1601-7 page $\mathrm{S}-60$

Adepoju OE, Bolin JN, Phillips CD, Zhao H, Ohsfeldt RL, McMaughan DK, Helduser JW, Forjuoh SN. Effects of diabetes self-management programs on time-to-hospitalization among patients with type 2 diabetes: a survival analysis model. Patient Educ Couns 2014; 95: 111-17 page $\mathrm{S}-58$

Ambery P, Donner TW, Biswas N, Donaldson J, Parkin J, Dayan CM. Efficacy and safety of low-dose otelixizumab anti-CD3 monoclonal antibody in preserving C-peptide secretion in adolescent type 1 diabetes: DEFEND-2, a randomized, placebo-controlled, double-blind, multi-center study. Diabetic Med 2014; 31: 399-402

page $\mathrm{S}-82$

American Diabetes Association Standards of Medical Care in Diabetes. Diabetes Care 2014; 37 Supplement 1: S14-80 page S-67

Ando K, Nishimura R, Tsujino D, Seo C, Utsunomiya K. 24hour glycemic variations in drug-naïve patients with type 2 diabetes: a continuous glucose monitoring (CGM)-based study. PLoS One 2013; 8: e71102 page S-17

Arnhold M, Quade M, Kirch W. Mobile applications for diabetics: a systematic review and expert-based usability evaluation considering the special requirements of diabetes patients age 50 years or older. J Med Internet Res 2014; 16: e104 page $\mathrm{S}-56$

Aronson R, Gibney MA, Oza K, Bérubé J, Kassler-Taub K, Hirsch L. Insulin pen needles: effects of extra-thin wall needle technology on preference, confidence, and other patient ratings. Clin Ther 2013; 35: 923-33 page S-49

Aronson R, Gottlieb PA, Christiansen JS, Donner TW, Bosi E, Bode BW, Pozzilli P; for the DEFEND Investigator Group. Low-dose otelixizumab anti-CD3 monoclonal antibody DEFEND-1 Study: results of the randomized phase III study in recent-onset human type 1 diabetes. Diabetes Care 2014; 37: 2746-54 page S-82

Bailey TS, Ahmann A, Brazg R, Christiansen M, Garg S, Watkins E, Welsh JB, Lee S. Accuracy and acceptability of the 6-day Enlite continuous subcutaneous glucose sensor.
Diabetes Technol Ther 2014; 16: 277-83

page $\mathrm{S}-110$

Balli S, Pac FA, Ece İ, Oflaz MB, Kibar AE, Kandemir ö. Assessment of cardiac functions in fetuses of gestational diabetic mothers. Pediatr Cardiol 2014; 35: 30-37 page $\mathrm{S}-73$

Bao W, Bowers K, Tobias DK, Hu FB, Zhang C. Prepregnancy dietary protein intake, major dietary protein sources, and the risk of gestational diabetes mellitus: a prospective cohort study. Diabetes Care 2013; 36: 2001-8. page $\mathrm{S}-72$

Barnea-Goraly N, Raman M, Mazaika P, Marzelli M, Hershey T, Weinzimer SA, Aye T, Buckingham B, Mauras N, White NH, Fox LA, Tansey M, Beck RW, Ruedy KJ, Kollman C, Cheng P, Reiss AL. Diabetes Research in Children Network (DirecNet). Alterations in white matter structure in young children with type 1 diabetes. Diabetes Care 2014; 37: 332-40

pages $\mathrm{S}-97$ and $\mathrm{S}-111$

Barnett AH, Huisman H, Jones R, von Eynatten M, Patel S, Woerle HJ. Linagliptin for patients aged 70 years or older with type 2 diabetes inadequately controlled with common antidiabetes treatments: a randomised, double-blind, placebocontrolled trial. Lancet 2013; 382: 1413-23

page $S-121$

Beck RW, Raghinaru D, Wadwa RP, Chase HP, Maahs DM, Buckingham B. Frequency of morning ketosis after overnight insulin suspension using an automated nocturnal predictive low-glucose suspend system. Diabetes Care 2014; 37: $1224-29$

page $\mathrm{S}-100$

Beratarrechea A, Lee AG, Willner JM, Jahangir E, ' $n$ Ciapponi A, Rubinstein A. The impact of mobile health interventions on chronic disease outcomes in developing countries: a systematic review. Telemed J e-Health 2014; 20: $75-82$

page S-64

Bergenstal RM, Rosenstock J, Bastyr III EJ, Prince MJ, Qu Y, Jacober SJ. Lower glucose variability and hypoglycemia measured by continuous glucose monitoring with novel longacting insulin LY2605541 versus insulin glargine. Diabetes Care 2014; 37: 659-65

page $\mathrm{S}-43$

Biester T, Blaesig S, Remus K, Aschemeier B, Kordonouri O, Granhall C, Søndergaard F, Kristensen NR, Haahr H, Danne T. Insulin degludec's ultra-long pharmacokinetic properties observed in adults are retained in children and adolescents with type 1 diabetes. Pediatr Diabetes 2014; 15: $27-33$

page $\mathrm{S}-40$

Blumer I, Hadar E, Hadden DR, Jovanovic L, Mestman JH, Murad MH, Yogev Y. Diabetes and pregnancy: an Endocrine 
Society clinical practice guideline. J Clin Endocrinol Metab 2013; 11: 4227-49

page $\mathrm{S}-67$

Böhme T, Engel CK, Farjot G, Güssregen S, Haack T, Tschank G, Ritter K. 1,1-Dioxo-5,6-dihydro-[4,1,2]oxathiazines, a novel class of $11 \beta$-HSD1 inhibitors for the treatment of diabetes. Bioorg Med Chem Lett 2013; 23: 4685-91

page S-131

Bohnet J, Schmitz M, Kamlot S, Abdel-Tawab M. Dosing accuracy and insulin flow rate characteristics of a new disposable insulin pen, FlexTouch, compared with SoloSTAR. J Diabetes Sci Technol 2013; 7: 1021-26

page $\mathrm{S}-48$

Bosi E, Scavini M, Ceriello A, Cucinotta D, Tiengo A, Marino R, Bonizzoni E, Giorgino F; PRISMA Study Group. Intensive structured self-monitoring of blood glucose and glycemic control in non-insulin-treated type 2 diabetes: the PRISMA randomized trial. Diabetes Care 2013; 36: 2887-94 page $\mathrm{S}-5$

Breton MD, Brown SA, Karvetski CH, Kollar L, Topchyan KA, Anderson SM, Kovatchev BP. Adding heart rate signal to a control-to-range artificial pancreas system improves the protection against hypoglycemia during exercise in type 1 diabetes. Diabetes Technol Ther 2014; 16: 506-11 page $\mathrm{S}-90$

Buckingham B, Beck RW, Ruedy KJ, Cheng P, Kollman C, Weinzimer SA, DiMeglio LA, Bremer AA, Slover R, Tamborlane WV; Diabetes Research in Children Network (DirecNet) Study Group; Type 1 Diabetes TrialNet Study Group. Effectiveness of early intensive therapy on $\beta$-cell preservation in type 1 diabetes. Diabetes Care 2013; 36: 4030-35 page $\mathrm{S}-104$

Buse JB, Vilsbøll T, Thurman J, Blevins TC, Langbakke IH, Bøttcher SG, Rodbard HW; on behalf of the NN9068-3912 (DUAL-II) Trial Investigators. Contribution of liraglutide in the fixed-ratio combination of insulin degludec and liraglutide (IDegLira). Diabetes Care 2014; 37: 2926-33 page $\mathrm{S}-128$

Campbell MS, Schatz DA, Chen V, Wong JC, Steck A, Tamborlane WV, Smith J, Beck RW, Cengiz E, Laffel LM, Miller KM, Haller MJ; T1D Exchange Clinic Network. A contrast between children and adolescents with excellent and poor control: the T1D Exchange Clinic Registry experience. Pediatr Diabetes 2014; 15: 110-17

page $\mathrm{S}-107$

Cengiz C, Weinzimer SA, Sherr JL, Tichy EM, Carria L, Cappiello D, Steffen A, Tamborlane WV. Faster in and faster out: accelerating insulin absorption and action by insulin infusion site warming. Diabetes Technol Ther 2014; 16: $20-25$

page S-98

Chang T, Chopra V, Zhang C, Woolford SJ. The role of social media in online weight management: systematic review. $J$ Med Internet Res 2013; 15: e262

page $\mathrm{S}-62$

Chaudhry T, Klonoff DC. SMBG out of control: the need for educating patients about control solution. Diabetes Educ 2013; 39: 689-95

page $\mathrm{S}-8$

Chavey A, Kioon A, Bailbé D, Movassat J, Portha B. Maternal diabetes, programming of beta-cell disorders and intergenerational risk of type 2 diabetes. Diabetes Metab 2014; 40: 323-30

page $S-71$
Choudhary P, Davies C, Emery CJ, Heller SR. Do high fasting glucose levels suggest nocturnal hypoglycemia? The Somogyi effect-more fiction than fact? Diabetic Med 2013; 30: 914-17

page $\mathrm{S}-8$

Choudhary P, Ramasamy S, Green L, Gallen G, Pender S, Brackenridge A, Amiel SA, Pickup J. Real-time continuous glucose monitoring significantly reduces severe hypoglycemia in hypoglycemia-unaware patients with type 1 diabetes. Diabetes Care 2013; 36: 4160-62

pages S-14, S-22 and S-112

Colberg SR, Hernandez MJ, Shahzad F. Blood glucose responses to type, intensity, duration, and timing of exercise. Diabetes Care 2013; 36: e177 page S-88

Crenier L, Abou-Elias C, Corvilain B. Glucose variability assessed by low blood glucose index is predictive of hypoglycemic events in patients with type 1 diabetes switched to pump therapy. Diabetes Care 2013; 36: 2148-53 page $\mathrm{S}-8$

D’Addio F, Valderrama Vasquez A, Ben Nasr M, Franek E, Zhu D, Li L, Ning G, Snarski E, Fiorina P. Autologous nonmyeloablative hematopoietic stem cell transplantation in new-onset type 1 diabetes: a multicenter analysis. Diabetes 2014; 63: 3041-46 page $\mathrm{S}-85$

Danne T, Tsioli C, Kordonouri O, Blaesig S, Remus K, Roy A, Keenan B, Lee S, Kaufman FR. The PILGRIM Study: in silico modeling of a predictive low-glucose management system and feasibility in youth with type 1 diabetes during exercise. Diabetes Technol Ther 2013; 16: 338-47 pages $\mathrm{S}-22$ and $\mathrm{S}-100$

Davies MJ, Gross JL, Ono Y, Sasaki T, Bantwal G, Gall MA, Niemeyer M, Seino H on behalf of the BEGIN BB11 study group. Efficacy and safety of insulin degludec given as part of basal-bolus treatment with mealtime insulin aspart in type 1 diabetes: a 26-week randomized, open-label, treat-totarget non-inferiority trial. Diabetes Obes Metab 2014; 16: 922-30

page S-39

del Rosario MC, Ossowski V, Knowler WC, Bogardus C, Baier LJ,. Hanson RL. Potential epigenetic dysregulation of genes associated with MODY and type 2 diabetes in humans exposed to a diabetic intrauterine environment: an analysis of genomewide DNA methylation. Metabolism 2014; 63: 654-60 page $S-71$

DeSalvo DJ, Keith-Hynes P, Peyser T, Place J, Caswell K, Wilson DM, Harris B, Clinton P, Kovatchev B, Buckingham BA. Remote glucose monitoring in camp setting reduces the risk of prolonged nocturnal hypoglycemia. Diabetes Technol Ther 2014; 16: 1-7

page $\mathrm{S}-101$

DiPietro J, Gribok A, Stevens MS, Hamm LF, Rumpler W. Three 15-minute bouts of moderate postmeal walking significantly improve $24 \mathrm{~h}$ glycemic control in older people at risk for impaired glucose tolerance. Diabetes Care 2013; 36: 3262-68

page $\mathrm{S}-91$

Egli L, Lecoultre V, Theytaz F, Campos V, Hodson L, Schneiter P, Mittendorfer B, Patterson BW, Fielding BA, Gerber PA, Giusti V, Berneis K, Tappy L. Exercise prevents fructose-induced hypertriglyceridemia in healthy young subjects. Diabetes 2013; 62: 2259-65

page S-94 
El-Khatib FH, Russell SJ, Magyar KL, Sinha M, McKeon K, Nathan DM, Damiano ER. Autonomous and continuous adaptation of a bihormonal bionic pancreas in adults and adolescents with type 1 diabetes. J Clin Endocrinol Metab 2014; 99: $1701-11$

page $\mathrm{S}-32$

Evans JM, Mackison D, Swanson V, Donnan PT, Emslie-Smith A, Lawton J. Self-monitoring of blood glucose in type 2 diabetes: patients' perceptions of "high" readings. Diabetes Res Clin Pract 2013; 102: e5-7 page $\mathrm{S}-6$

Fang F, Xiao H, Li C, Tian H, Li J, Li Z, Cheng X. Fasting glucose level is associated with nocturnal hypoglycemia in elderly male patients with type 2 diabetes. Aging Male 2013; 16: $132-36$ page $\mathrm{S}-4$

Finan DA, McCann TW Jr., Mackowiak L, Dassau E, Patek SD, Kovatchev BP, Doyle III FJ, Zisser H, Anhalt H, Venugopalan R. Closed-loop control performance of the hypoglycemia-hyperglycemia minimizer (HHM) system in a feasibility study. J Diabetes Sci Technol 2014; 8: 35-42 page S-36

Friedrichs A, Bohnet J, Korger V, Adler S, Schubert-Zsilavecz M, Abdel-Tawab M. Dose accuracy and injection force of different insulin glargine pens. J Diabetes Sci Technol 2013; 7: $1346-53$

page $\mathrm{S}-47$

Fukuhara T, Hyogo H, Ochi H, Fujino H, Kan H, Naeshiro N, Honda Y, Miyaki D, Kawaoka T, Tsuge M, Hiramatsu A, Imamura M, Kawakami Y, Aikata H, Chayama K. Efficacy and safety of sitagliptin for the treatment of nonalcoholic fatty liver disease with type 2 diabetes mellitus. Hepatogastroenterology 2014; 61: 323-28 page $\mathrm{S}-122$

Garg SK, Brazg RL, Bailey TS, Buckingham BA, Slover RH, Klonoff DC, Shin J, Welsh JB, Kaufman FR. Hypoglycemia begets hypoglycemia: the order effect in the ASPIRE inclinic study. Diabetes Technol Ther 2014; 16: 125-30 page S-93

Garg SK, Buse JB, Skyler JS, Vaughn DE, Muchmore DB. Subcutaneous injection of hyaluronidase with recombinant human insulin compared with insulin lispro in type 1 diabetes. Diabetes Obes Metab 2014; 16: 1065-9 page S-45

Gomes MB, Tannus LR, Cobas RA, Matheus AS, Dualib P, Zucatti AT, Cani C, Guedes AD, Santos FM, Sepulveda J, Tolentino M, Façanha MC, Faria AC, Lavigne S, Montenegro AP, Rodacki M, de Fatima Guedes M, Szundy R, Cordeiro MM, Santos PT, Negrato CA; Brazilian Type 1 Diabetes Study Group (BrazDiab1SG). Determinants of self-monitoring of blood glucose in patients with type 1 diabetes: a multicenter study in Brazil. Diabetic Med 2013; 30: 1255-62 page $S-6$

Gondhalekar R, Dassau E, Zisser HC, Doyle III FJ. Periodic zonemodel predictive control for diurnal closed-loop operation of an artificial pancreas. J Diabetes Sci Technol 2013; 7: 1446-60 page $\mathrm{S}-35$

Gottlieb PA, Alkanani AK, Michels AW, Lewis EC, Shapiro L, Dinarello CA, Zipris D. $\alpha 1$-Antitrypsin therapy downregulates toll-like receptor-induced IL-1 $\beta$ responses in monocytes and myeloid dendritic cells and may improve islet function in recently diagnosed patients with type 1 diabetes. J Clin Endocrinol Metab 2014; 99: E1418-26 page $\mathrm{S}-86$
Gough SC, Bhargava A, Jain R, Mersebach H, Rasmussen S, Bergenstal RM. Low-volume insulin degludec 200 units/ $\mathrm{mL}$ once daily improves glycemic control similarly to insulin glargine with a low risk of hypoglycemia in insulinnaïve patients with type 2 diabetes: a 26 -week, randomized, controlled, multinational, treat-to-target trial: the BEGIN LOW VOLUME trial. Diabetes Care 2013; 36: 2536-42

page $\mathrm{S}-128$

Grady M, Campbell D, MacLeod K, Srinivasan A. Evaluation of a blood glucose monitoring system with automatic highand low-pattern recognition software in insulin-using patients: pattern detection and patient-reported insights. $J$ Diabetes Sci Technol 2013; 7: 970-78

page $\mathrm{S}-10$

Griffin KJ, Thompson PA, Gottschalk M, Kyllo JH, Rabinovitch A. Combination therapy with sitagliptin and lansoprazole in patients with recent-onset type 1 diabetes (REPAIR-T1D): 12-month results of a multicentre, randomised, placebocontrolled, phase 2 trial. Lancet Diabetes Endocrinol 2014; 2: $710-18$ page $\mathrm{S}-82$

Han J, Sun L, Chu Y, Li Z, Huang D, Zhu X, Qian H, Huang W. Design, synthesis, and biological activity of novel dicoumarol glucagon-like peptide 1 conjugates. $\mathrm{J}$ Med Chem 2013; 56: 9955-68

page $\mathrm{S}-124$

Hartemann A, Bensimon G, Payan CA, Jacqueminet S, Bourron O, Nicolas N, Fonfrede M, Rosenzwajg M, Bernard C, Klatzmann D. Low-dose interleukin 2 in patients with type 1 diabetes: a phase 1/2 randomized, double-blind, placebocontrolled trial. Lancet Diabetes Endocrinol 2013; 1: 295305

page $\mathrm{S}-85$

Harvey RA, Dassau E, Bevier WC, Seborg DE, Jovanovic L, Doyle III FJ, Zisser HC. Clinical evaluation of an automated artificial pancreas using zone-model predictive control and health monitoring System. Diabetes Technol Ther 2014; 16: 348-57 page $\mathrm{S}-30$

Heise T, Nosek L, Dellweg S, Zijlstra E, Præstmark KA, Kildegaard J, Nielsen G, Sparre T. Impact of injection speed and volume on perceived pain during subcutaneous injections into the abdomen and thigh: a single-center, randomized controlled trial. Diabetes Obesity Metab 2014; 16: $971-6$ page $S-48$

Henry RR, Mudaliar S, Ciaraldi TP, Armstrong DA, Burke P, Pettus J, Garhyan P, Choi SL, Jacober SJ, Knadler MP, Quin Lam EC, Prince MJ, Bose N, Porksen N, Sinha VP, Linnebjerg $\mathrm{H}$. Basal insulin peglispro demonstrates preferential hepatic versus peripheral action relative to insulin glargine in healthy subjects. Diabetes Care 2014; 37: 2609-15 page $\mathrm{S}-44$

Hensen J, Howard CP, Walter V, Thuren T. Impact of interleukin-1 $\beta$ antibody (canakinumab) on glycemic indicators in patients with type 2 diabetes mellitus: results of secondary endpoints from a randomized, placebo-controlled trial. Diabetes Metab 2013; 39: 524-31

page $\mathrm{S}-129$

Herdman ML, Larck C, Schliesser SH, Jelic TM. Biological contamination of insulin pens in a hospital setting. Am J Health Syst Pharm 2013; 70: 1244-48

page $\mathrm{S}-49$ 
Holt P. Blood glucose monitoring in diabetes. Nurs Stand 2014; 28: $52-58$

page $\mathrm{S}-3$

Hovorka R, Elleri D, Thabit H, Allen JM, Leelarathna L, ElKhairi R, Kumareswaran K, Caldwell K, Calhoun P, Kollman C, Murphy HR, Acerini CL, Wilinska ME, Nodale M, Dunger DB. Overnight closed-loop insulin delivery in young people with type 1 diabetes: a free-living, randomized clinical trial. Diabetes Care 2014; 37: 1204-11

pages S-28 and S-102

Ikramuddin S, Korner J, Lee WJ, Connett JE, Inabnet WB, Billington CJ, Thomas AJ, Leslie DB, Chong K, Jeffery RW, Ahmed L, Vella A, Chuang LM, Bessler M, Sarr MG, Swain JM, Laqua P, Jensen MD, Bantle JP. Roux-en-Y gastric bypass vs intensive medical management for the control of type 2 diabetes, hypertension, and hyperlipidemia: the Diabetes Surgery Study randomized clinical trial. JAMA 2013; 309: $2240-49$

page $\mathrm{S}-77$

Josse RG, Woo V. Flexibly timed once-daily dosing with degludec: a new ultra-long-acting basal insulin. Diabetes Obes Metab 2013; 15: 1077-84

page $\mathrm{S}-127$

Joubert M, Morera J, Vicente A, Rod A, Perienti J-J, Reznik Y. Cross-sectional survey and retrospective analysis of a large cohort of adults with type 1 diabetes with long-term continuous subcutaneous insulin infusion treatment. J Diabet Sci Technol 2014; 8: 1005-10

page $\mathrm{S}-23$

Kadowaki T, Kondo K. Efficacy, safety, and dose-response relationship of teneligliptin, a dipeptidyl peptidase- 4 inhibitor, in Japanese patients with type 2 diabetes mellitus. Diabetes Obes Metab 2013; 15: 810-18 page $\mathrm{S}-123$

Karstoft K, Christensen CS, Pedersen BK, Solomon TP. The acute effects of interval- vs. continuous-walking exercise on glycemic control in subjects with type 2 diabetes: a crossover, controlled study. J Clin Endocrinol Metab 2014; 99: 3334-42

page $\mathrm{S}-18$

Kim SR, Kim DH, Park SH, Kim YS, Kim CH, Ha TY, Yang J, Rhee JK. In vivo efficacy of HD0471953: a novel GPR119 agonist for the treatment of type 2 diabetes mellitus. $J$ Diabetes Res 2013; 269569 doi: 10.1155/2013/269569. Epub 2013 Dec 12

page $\mathrm{S}-131$

Kirwan M, Vandelanotte C, Fenning A, Duncan MJ. Diabetes self-management smartphone application for adults with type 1 diabetes: randomized controlled trial. J Med Internet Res 2013; 15: e235

page S-56

Klingensmith GJ, Aisenberg J, Kaufman F, Halvorson M, Cruz E, Riordan ME, Varma C, Pardo S, Viggiani MT, Wallace JF, Schachner HC, Bailey T. Evaluation of a combined blood glucose monitoring and gaming system (Didget ${ }^{\circledR}$ ) for motivation in children, adolescents, and young adults with type 1 diabetes. Pediatr Diabetes 2013; 14: $350-57$

page $\mathrm{S}-9$

Klonoff DC, Reyes JS. Do currently available blood glucose monitors meet regulatory standards? One-day public meeting in Arlington, Virginia. J Diabetes Sci Technol 2013; 7: 1071-83

page $\mathrm{S}-9$
Knip M, Åkerblom HK, Becker D, Dosch HM, Dupre J, Fraser W, Howard N, Ilonen J, Krischer JP, Kordonouri O, Lawson ML, Palmer JP, Savilahti E, Vaarala O, Virtanen SM; TRIGR Study Group. Hydrolyzed infant formula and early $\beta$-cell autoimmunity: a randomized clinical trial. JAMA 2014; 311: 2279-87 page $\mathrm{S}-80$

Koehler G, Heller S, Korsatko S, Roepstorff C, Rasmussen S, Haahr H, Pieber TR. Insulin degludec is not associated with a delayed or diminished response to hypoglycemia compared with insulin glargine in type 1 diabetes: a double-blind randomized crossover study. Diabetologia 2014; 57: 40-49 page $\mathrm{S}-40$

Kovatchev BP, Renard E, Cobelli C, Zisser HC, Keith-Hynes P, Anderson SM, Brown SA, Chernavvsky DR, Breton MD, Farret A, Pelletier MJ, Place J, Bruttomesso D, Del Favero S, Visentin R, Filippi A, Scotton R, Avogaro A, Doyle III FJ. Feasibility of outpatient fully integrated closed-loop control. Diabetes Care 2013; 36: 1851-58

page $\mathrm{S}-31$

Kramer CK, Choi H, Zinman B, Retnakaran R. Determinants of reversibility of $\beta$-cell dysfunction in response to short-term intensive insulin therapy in patients with early type 2 diabetes. Am J Physiol Endocrinol Metab 2013; 305: E1398-407 page S-127

Kumareswaran K, Thabit H, Leelarathna L, Caldwell K, Elleri D, Allen JM, Nodale M, Wilinska ME, Evans ML, Hovorka R. Feasibility of closed-loop insulin delivery in type 2 diabetes: a randomized controlled study. Diabetes Care 2014; 37: 1198-203

page $S-33$

Landau Z, Rachmiel M, Pinhas-Hamiel O, Boaz M, Bar-Dayan Y, Wainstein J, Tauman R. Parental sleep quality and continuous glucose monitoring system use in children with type 1 diabetes. Acta Diabetol 2014; 51: 499-503 page S-14

Lanzola G, Scarpellini S, Di Palma F, Toffanin C, Del Favero S, Magni L, Bellazzi R, on behalf of the AP@home consortium. Monitoring artificial pancreas trials through agentbased technologies: a case report. J Diabetes Sci Technol 2014; 8: 216-24

page $\mathrm{S}-34$

Leahey T, Rosen J. DietBet: a web-based program that uses social gaming and financial incentives to promote weight loss. JMIR Serious Games 2014; 2: e2 page $\mathrm{S}-62$

Lee CG, Schwartz AV, Yaffe K, Hillier TA, LeBlanc ES, Cawthon PM, for the Study of Osteoporotic Fractures Research Group. Changes in physical performance in older women according to presence and treatment of diabetes mellitus. J Am Geriatr Soc 2013; 61: 1872-78 page $\mathrm{S}-92$

Li L, Shen J, Bala MM, Busse JW, Ebrahim S, Vandvik PO, Rios LP, Malaga G, Wong E, Sohani Z, Guyatt GH, Sun X. Incretin treatment and risk of pancreatitis in patients with type 2 diabetes mellitus: systematic review and meta-analysis of randomised and non-randomised studies. BMJ 2014; 348: g2366

page $\mathrm{S}-119$

Li YY, Yu LF, Zhang LN, Qiu BY, Su MB, Wu F, Chen DK, Pang T, Gu M, Zhang W, Ma WP, Jiang HW, Li JY, Nan FJ, Li J. Novel small-molecule AMPK activator orally exerts beneficial effects on diabetic $\mathrm{db} / \mathrm{db}$ mice. Toxicol Appl Pharmacol 2013; 273: 325-34

page $\mathrm{S}-130$ 
Lin $\mathrm{MH}$, Connor CG, Ruedy KJ, Beck RW, Kollman C, Buckingham B, Redondo MJ, Schatz D, Haro H, Lee JM, Tamborlane WV, Wood JR, for the Pediatric Diabetes Consortium. Race, socioeconomic status, and treatment center are associated with insulin pump therapy in youth in the first year following diagnosis of type 1 diabetes. Diabetes Technol Ther 2013; 15: 929-34 page S-116

Little SA, Leelarathna L, Walkinshaw E, Tan HK, Chapple O, Lubina-Solomon A, Chadwick TJ, Barendse S, Stocken DD, Brennand C, Marshall SM, Wood R, Speight J, Kerr D, Flanagan D, Heller SR, Evans ML, Shaw JA. Recovery of hypoglycemia awareness in long-standing type 1 diabetes: a multicenter $2 \times 2$ factorial randomized controlled trial comparing insulin pump with multiple daily injections and continuous with conventional glucose self-monitoring (HypoCOMPaSS). Diabetes Care 2014; 37: 2114-22 page $\mathrm{S}-112$

Liu Y, Wu Y, Wu H, Tang L, Wu P, Liu T, Hu Y. Design, synthesis, biological evaluation, and docking studies of (S)phenylalanine derivatives with a 2-cyanopyrrolidine moiety as potent dipeptidyl peptidase 4 inhibitors. Chem Biol Drug Des 2013; 82: 140-46

page $\mathrm{S}-124$

Luijf YM, DeVries JH, Zwinderman K, Leelarathna L, Nodale M, Caldwell K, Kumareswaran K, Elleri D, Allen JM, Wilinska ME, Evans ML, Hovorka R, Doll W, Ellmerer M, Mader JK, Renard E, Place J, Farret A, Cobelli C, Del Favero S, Dalla Man C, Avogaro A, Bruttomesso D, Filippi A, Scotton R, Magni L, Lanzola G, Di Palma F, Soru P, Toffanin C, De Nicolao G, Arnolds S, Benesch C, Heinemann L. Day and night closed-loop control in adults with type 1 diabetes: a comparison of two closed-loop algorithms driving continuous subcutaneous insulin infusion versus patient selfmanagement. Diabetes Care 2013; 36: 3882-87 page $\mathrm{S}-30$

Ly TT, Nicholas JA, Retterath A, Lim EM, Davis EA, Jones TW. Effect of sensor-augmented insulin pump therapy and automated insulin suspension vs standard insulin pump therapy on hypoglycemia in patients with type 1 diabetes. JAMA 2013; 310: 1240-47

pages $\mathrm{S}-15$ and $\mathrm{S}-21$

Maahs DM, Chase HP, Westfall E, Slover R, Huan S, Shin JJ, Kaufman FR, Pyle L, Snell-Bergeon JK. The effects of lowering nighttime and breakfast glucose levels with sensoraugmented pump therapy on hemoglobin A1c levels in type 1 diabetes. Diabetes Technol Ther 2014; 16: 284-91 pages S-12 and S-99

Maher CA, Lewis LK, Ferrar K, Marshall S, De Bourdeaudhuij I, Vandelanotte C. Are health behavior change interventions that use online social networks effective? A systematic review. J Med Internet Res 2014; 16: e40 page S-61

Mandl KD, McNabb M, Marks N, Weitzman ER, Kelemen S, Eggleston EM, Quinn M. Participatory surveillance of diabetes device safety: a social media-based complement to traditional FDA reporting. J Am Med Inform Assoc 2014; 21: 687-91

page S-51

Marcolino MS, Maia JX, Alkmim MBM, Boersma E, Ribeiro A. Telemedicine application in the care of diabetes patients: systematic review and meta-analysis. PLoS One 2013; 8: e79246

page $\mathrm{S}-55$
Marek-Trzonkowska N, Myśliwiec M, Dobyszuk A, Grabowska M, Derkowska I, Juścińska J, Owczuk R, Szadkowska A, Witkowski P, Młynarski W, Jarosz-Chobot P, Bossowski A, Siebert J, Trzonkowski P. Therapy of type 1 diabetes with CD4(+)CD25(high)CD127-regulatory $\mathrm{T}$ cells prolongs survival of pancreatic islets-results of one year follow-up. Clin Immunol 2014; 153: 23-30 page $\mathrm{S}-84$

Mauseth R, Hirsch IB, Bollyky J, Kircher R, Matheson D, Sanda S, Greenbaum C. Use of a "fuzzy logic" controller in a closed-loop. Diabetes Technol Ther 2013; 15: 628-33 page $\mathrm{S}-29$

McCully SN, Don BP, Updegraff JA. Using the Internet to help with diet, weight, and physical activity: results from the Health Information National Trends Survey (HINTS). J Med Internet Res 2013; 15: e148

page $\mathrm{S}-63$

Meade LT, Rushton WE. Optimizing insulin pump therapy: a quality improvement project. Diabetes Educ 2013; 39: 841-47. page $\mathrm{S}-113$

Mingrone G, Panunzi S, De Gaetano A, Guidone C, Iaconelli A, Leccesi L, Nanni G, Pomp A, Castagneto M, Ghirlanda G, Rubino F. Bariatric surgery versus conventional medical therapy for type 2 diabetes. N Engl J Med 2012; 366: 1577-85 page $\mathrm{S}-77$

Mitchell K, Johnson K, Cullen K, Lee MM, Hardy OT. Parental mastery of continuous subcutaneous insulin infusion skills and glycemic control in youth with type 1 diabetes. Diabetes Technol Ther 2013; 15: 591-95.

page $\mathrm{S}-114$

Monnier L, Colette C, Dejager S, Owens D. Residual dysglycemia when at target $\mathrm{HbAlc}$ of $7 \%(53 \mathrm{mmol} / \mathrm{mol})$ in persons with type 2 diabetes. Diabetes Res Clin Pract 2014; 104: 370-75 page $\mathrm{S}-16$

Moreno-Fernandez J, Gomez FJ, Gazquez M, Pedroche M, García-Manzanares A, Tenias JM, Benito P, Gomez IR. Real-time continuous glucose monitoring or continuous subcutaneous insulin infusion, what goes first?: results of a pilot study. Diabetes Technol Ther 2013; 15: 596-600 page $\mathrm{S}-111$

Motawi TM, Bustanji Y, El-Maraghy SA, Taha MO, Al Ghussein MA. Naproxen and cromolyn as new glycogen synthase kinase $3 \beta$ inhibitors for amelioration of diabetes and obesity: an investigation by docking simulation and subsequent in vitro/in vivo biochemical evaluation. J Biochem Mol Toxicol 2013; 27: 425-36

page $\mathrm{S}-130$

Nimri R, Muller I, Atlas E, Miller S, Kordonouri O, Bratina N, Tsioli C, Stefanija MA, Danne T, Battelino T, Phillip M. Night glucose control with MD-Logic artificial pancreas in home setting: a single, blind, randomized, crossover trialinterim analysis. Pediatr Diabetes 2014; 15: 91-99 pages $\mathrm{S}-27$ and $\mathrm{S}-103$

Nixon R, Folwell R, Pickup JC. Variations in the quality and sustainability of long-term glycemic control with continuous subcutaneous insulin infusion. Diabetic Med 2014; 31: 11741177

page $\mathrm{S}-23$

ORIGIN Trial Investigators, Mellbin LG, Rydén L, Riddle MC, Probstfield J, Rosenstock J, Díaz R, Yusuf S, Gerstein HC. Does hypoglycemia increase the risk of cardiovascular events? A report from the ORIGIN trial. Eur Heart J 2013; 34: $3137-44$

page S-127 
Page KA, Romero A, Buchanan TA, Xiang AH. Gestational diabetes mellitus, maternal obesity, and adiposity in offspring. J Pediatr 2014; 164: 807-10 page $\mathrm{S}-75$

Pal K, Eastwood SV, Michie S, Farmer A, Barnard ML, Peacock R, Wood B, Edwards P, Murray E. Computer-based interventions to improve self-management in adults with type 2 diabetes: a systematic review and meta-analysis. Diabetes Care 2014; 37: 1759-66

page $\mathrm{S}-58$

Pickup JC, Yemane N, Brackenridge A, Pender S. Nonmetabolic complications of continuous subcutaneous insulin infusion: a patient survey. Diabet Technol Therapeut 2014; 16: 145-49 page $\mathrm{S}-24$

Place J, Robert A, Ben Brahim N, Keith-Hynes P, Farret A, Pelletier MJ, Buckingham B, Breton M, Kovatchev B, Renard E. DiAs Web monitoring: a real-time remote monitoring system designed for artificial pancreas outpatient trials. $J$ Diabetes Sci Technol 2013; 7: 1427-35 page S-34

Pozzilli P, Raz I, Peled D, Elias D, Avron A, Tamir M, Eren R, Dagan S, Cohen IR. Evaluation of long-term treatment effect in a type 1 diabetes intervention trial: differences after stimulation with glucagon or a mixed meal. Diabetes Care 2014; 37: 1384-91

page $\mathrm{S}-83$

Qiu C, Enquobahrie DA, Frederick IO, Sorenson TL, Fernandez MAL, David RM, Bralley JA, Williams MA. Early pregnancy urinary biomarkers of fatty acid and carbohydrate metabolism in pregnancies complicated by gestational diabetes. Diabetes Res Clin Pract 2014; 104: 393-400 page $\mathrm{S}-68$

Ramachandran A, Snehalatha C, Ram J, Selvam S, Simon M, Nanditha A, Shetty AS, Godsland IF, Chaturvedi N, Majeed A, Oliver N, Toumazou C, Alberti KG, Johnston DG. Effectiveness of mobile phone messaging in prevention of type 2 diabetes by lifestyle modification in men in India: a prospective, parallel-group, randomized controlled trial. Lancet Diabetes Endocrinol 2013; 1: 191-98

page S-65

Ramljak S, Musholt PB, Schipper C, Flacke F, Sieber J, Borchert M, Forst T, Pfützner A. The precision study: examining the inter- and intra-assay variability of replicate measurements of BGStar, iBGStar, and 12 other blood glucose monitors. Expert Opin Med Diagn 2013; 7: 511-16 page $\mathrm{S}-4$

Rasanen JP, Snyder CK, Rao PV, Mihalache R, Heinone S, Gravett MG, Roberts CT Jr., Nagalla SR. Glycosylated fibronectin as a first-trimester biomarker for prediction of gestational diabetes. Obstet Gynecol 2013; 122: 586-94 page S-68

Raz I, Ziegler AG, Linn T, Schernthaner G, Bonnici F, Distiller LA, Giordano C, Giorgino F, de Vries L, Mauricio D, Procházka V, Wainstein J, Elias D, Avron A, Tamir M, Eren R, Peled D, Dagan S, Cohen IR, Pozzilli P; DIA-AID 1 Writing Group. Treatment of recent-onset type 1 diabetic patients with DiaPep277: results of a double-blind, placebo-controlled, randomized phase 3 trial. Diabetes Care 2014; 37: 1392-400 page $\mathrm{S}-83$

Revert A, Garelli F, Pico J, De Battista H, Rossett P, Vehi J, Bondia J. Safety auxiliary feedback element for the artificial pancreas in type 1 diabetes. IEEE Trans Biomed Eng 2013; 60: $2113-22$

page $\mathrm{S}-35$
Reznik Y, Cohen O, Aronson R, Conget I, Runzis S, Castaneda J, Lee SW for the OpT2mise Study Group. Insulin pump treatment compared with multiple daily insulin injections for the treatment of type 2 diabetes (OpT2mise): a randomized open-label controlled trial. Lancet, 2014; 384(9950): 1265-72 page $\mathrm{S}-25$

Rigby MR, DiMeglio LA, Rendell MS, Felner EI, Dostou JM, Gitelman SE, Patel CM, Griffin KJ, Tsalikian E, Gottlieb PA, Greenbaum CJ, Sherry NA, Moore WV, Monzavi R, Willi SM, Raskin P, Moran A, Russell WE, Pinckney A, KeyesElstein L, Howell M, Aggarwal S, Lim N, Phippard D, Nepom GT, McNamara J, Ehlers MR; T1DAL Study Team. Targeting of memory $\mathrm{T}$ cells with alefacept in new-onset type 1 diabetes (T1DAL study): 12 month results of a randomized, double-blind, placebo-controlled phase 2 trial. Lancet Diabetes Endocrinol 2013; 1: 284-94 page $\mathrm{S}-81$

Rodbard HW, Cariou B, Zinman B, Handelsman Y, PhilisTsimikas A, Skjøth TV, Rana A, Mathieu C on behalf of the BEGIN Once Long Trial Investigators. Comparison of insulin degludec with insulin glargine in insulin-naïve subjects with type 2 diabetes: a 2-year randomized, treat-to-target trial. Diabet Med 2013; 30: 1298-304

page S-41

Rosenstock J, Seman LJ, Jelaska A, Hantel S, Pinnetti S, Hach T, Woerle HJ. Efficacy and safety of empagliflozin, a sodium glucose cotransporter 2 (SGLT2) inhibitor, as add-on to metformin in type 2 diabetes with mild hyperglycaemia. Diabetes Obes Metab 2013; 15: 1154-60

page $\mathrm{S}-125$

Russell SJ, El-Khatib FH, Sinha M, Magyar KL, McKeon K, Goergen LG, Balliro C, Hillard MA, Nathan DM, Damiano ER. Outpatient glycemic control with a bionic pancreas in type 1 diabetes. $N$ Engl J Med 2014; 371: 313-25 page S-105

Sarwer DB, Ritter S, Wadden TA, Spitzer JC, Vetter ML, Moore RH. Physicians' attitudes about referring their type 2 diabetes patients for bariatric surgery. Surg Obes Relat Dis 2012; 8: 381-86

page $\mathrm{S}-78$

Scavini M, Bosi E, Ceriello A, Giorgino F, Porta M, Tiengo A, Vespasiani G, Bottalico D, Marino R, Parkin C, Bonizzoni E, Cucinotta D. Prospective, randomized trial on intensive SMBG management added value in non-insulin-treated T2DM patients (PRISMA): a study to determine the effect of a structured SMBG intervention. Acta Diabetol 2013; 50: $663-72$

page S-5

Schaeffer NE. Human factors research applied: the development of a personal touch screen insulin pump and users' perceptions of actual use. Diabetes Technol Ther 2013; 15: $845-54$

page S-109

Schauer PR, Bhatt DL, Kirwan JP, Wolski K, Brethauer SA, Navaneethan SD, Aminian A, Pothier CE, Kim ESH, Nissen SE, Kashyap SR; STAMPEDE Investigators. Bariatric surgery versus intensive medical therapy for diabetes-3-year outcomes. N Engl J Med 2014; 370: 2002-13 page S-76

Schiavon M, Dalla Man C, Kudva YC, Basu A, Cobelli C. Quantitative estimation of insulin sensitivity in type 1 diabetic subjects wearing a sensor-augmented insulin pump. Diabetes Care 2014; 37: 1216-23

page $\mathrm{S}-13$ 
Schnell O, Erbach M, Wintergerst E. Higher accuracy of selfmonitoring of blood glucose in insulin-treated patients in Germany: clinical and economical aspects. J Diabetes Sci Technol 2013; 7: 904-12 page $\mathrm{S}-10$

Shalitin S, Ben-Ari T, Yackobovitch-Gavan M, Tenenbaum A, Lebenthal Y, de Vries L, Phillip M. Using the Internet-based upload blood glucose monitoring and therapy management system in patients with type 1 diabetes. Acta Diabetol 2014; 51: $247-56$ page $S-106$

Schulz DN, Kremers SPJ, Vandelanotte C, van Adrichem MJG, Schneider F, Candel MJJM, de Vries H. Effects of a web-based tailored multiple-lifestyle intervention for adults: a two-year randomized controlled trial comparing sequential and simultaneous delivery modes. J Med Internet Res 2014; 16: e26 page $\mathrm{S}-54$

Schulz DN, Smit ES, Stanczyk NE, Kremers SPJ, de Vries H, Evers SMAA. Economic evaluation of a web-based tailored lifestyle intervention for adults: findings regarding costeffectiveness and cost-utility from a randomized controlled trial. J Med Internet Res 2014; 16: e91 page $\mathrm{S}-54$

Scifres CM, Feghali MN, Althouse AD, Caritis SN, Catov JM. Effect of excess gestational weight gain on pregnancy outcomes in women with type 1 diabetes. Obstetrics Gynecol 2014; 123: 1295-302 page $\mathrm{S}-73$

Scirica BM, Bhatt DL, Braunwald E, Steg PG, Davidson J, Hirshberg B, Ohman P, Frederich R, Wiviott SD, Hoffman EB, Cavender MA, Udell JA, Desai NR, Mosenzon O, McGuire DK, Ray KK, Leiter LA, Raz I; SAVOR-TIMI 53 Steering Committee and Investigators. Saxagliptin and cardiovascular outcomes in patients with type 2 diabetes mellitus. $N$ Engl J Med 2013; 369: 1317-26 page $\mathrm{S}-120$

Sequeira PA, Montoya L, Ruelas V, Xing D, Chen V, Beck R, Peters AL. Continuous glucose monitoring pilot in low-income type 1 diabetes patients. Diabetes Technol Ther 2013; 15: $855-58$ page $\mathrm{S}-116$

Sherr JL, Cengiz E, Palerm CC, Clark B, Kurtz N, Roy A, Carria L, Cantwell M, Tamborlane WV, Weinzimer SA. Reduced hypoglycemia and increased time in target using closed-loop insulin delivery during nights with or without antecedent afternoon exercise in type 1 diabetes. Diabetes Care 2013; 36: 2909-14 pages S-89 and S-103

Sherr J, Tsalikian E, Fox L, Buckingham B, Weinzimer S, Tamborlane W, White N, Arbelaez AM, Kollman C, Ruedy $\mathrm{K}$, Cheng P, Beck R, for the Diabetes Research in Children Network (DirecNet). Evolution of abnormal plasma glucagon responses to mixed-meal feedings in youth with type 1 diabetes during the first 2 years after diagnosis. Diabetes Care 2014; 37: 1741-44 page $\mathrm{S}-98$

Sinha VP, Howey DC, Choi SL, Mace KF, Heise T. Steadystate, pharmacokinetics and glucodynamics of the novel, long-acting basal insulin LY2605541 dosed once-daily in patients with type 2 diabetes mellitus. Diabetes Obes Metab 2014; 16: 344-50 page $S-43$

Steck AK, Dong F, Taki I, Hoffman M, Klingensmith GJ, Rewers MJ. Early hyperglycemia detected by continuous glucose monitoring in children at risk for type 1 diabetes Diabetes Care 2014; 37: 2031-33

page $\mathrm{S}-16$

Steinstraesser A, Schmidt R, Bergmann K, Dahmen R, Becker RHA. Investigational new insulin glargine $300 \mathrm{U} / \mathrm{ml}$ has the same metabolism as glargine $100 \mathrm{U} / \mathrm{ml}$. Diabetes Obes Metab 2014; 16: 873-6

page $\mathrm{S}-42$

Stellefson M, Chaney B, Barry AE, Chavarria E, Tennant B, Walsh-Childers K, Sriram PS, Zagora J. Web 2.0 chronic disease self-management for older adults: a systematic review. J Med Internet Res 2013; 15: e35 page $\mathrm{S}-57$

Tang J, Abraham C, Greaves C, Yates T. Self-directed interventions to promote weight loss: a systematic review of reviews. J Med Internet Res 2014; 16: e58 page $\mathrm{S}-60$

Tarapués M, Cereza G, Figueras A. Association of musculoskeletal complaints and gliptin use: review of spontaneous reports. Pharmacoepidemiol Drug Safety 2013; 22: 1115-18 page $S-121$

't Hart LM, Fritsche A, Nijpels G, van Leeuwen N, Donnelly LA, Dekker JM, Alssema M, Fadista J, Carlotti F, Gjesing AP, Palmer CN, van Haeften TW, Herzberg-Schäfer SA, Simonis-Bik AM, Houwing-Duistermaat JJ, Helmer Q, Deelen J, Guigas B, Hansen T, Machicao F, Willemsen G, Heine RJ, Kramer MH, Holst JJ, de Koning EJ, Häring HU, Pedersen O, Groop L, de Geus EJ, Slagboom PE, Boomsma DI, Eekhoff EM, Pearson ER, Diamant M. The CTRB1/2 locus affects diabetes susceptibility and treatment via the incretin pathway. Diabetes 2013; 62: 3275-81

page $\mathrm{S}-131$

Thompson H, Chan H, Logan FJ, Heenan HF, Taylor L, Murray C, Florkowski CM, Frampton CM, Lunt H. A glucose meter evaluation co-designed with both health professional and consumer input. $N$ Z Med J 2013; 126: 90-97 page $\mathrm{S}-3$

Tildesley HD, Wright AM, Chan JH, Mazanderani AB, Ross SA, Tildesley HG, Lee AM, Tang TS, White AS. A comparison of Internet monitoring with continuous glucose monitoring in insulin-requiring type 2 diabetes mellitus. Can J Diabetes 2013; 37: 305-8

page $\mathrm{S}-17$

Timmers S, Hesselink MK, Schrauwen P. Therapeutic potential of resveratrol in obesity and type 2 diabetes: new avenues for health benefits? Ann N Y Acad Sci 2013; 1290: 83-89 page $\mathrm{S}-131$

Tosun A, Duzguner S, Ozkaya E, Korkmaz V, Acar S, Gultekin B, Altinboga O, Duzguner IN, Kucukozkan T. Utility of superior mesenteric artery Doppler and maternal pancreatic size for predicting gestational diabetes mellitus. Ir J Med Sci 2014 Jun 8. [Epub ahead of print] DOI 10.1007/s11845-014-1155-7 page S-69

Trang LT, Nicholas JA, Retterath A, Lim EM, Davis EA, Jones T. Effect of sensor-augmented insulin pump therapy and automated insulin suspension vs. standard insulin pump therapy on hypoglycemia in patients with type 1 diabetes: a randomized clinical trial. JAMA 2013; 310: 1240-47 page $\mathrm{S}-99$

Trief PM, Sandberg JG, Dimmock JA, Forken PJ, Weinstock RS. Personal and relationship challenges of adults with type 1 diabetes: a qualitative focus group study. Diabetes Care 2013; 36: 2483-88

page $\mathrm{S}-115$ 
Turksoy K, Quinn L, Littlejohn E, Cinar A. Multivariable adaptive identification and control for artificial pancreas systems. IEEE Trans Biomed Eng 2014; 61: 883-91 page $\mathrm{S}-37$

van Bon AC, Luijf YM, Koebrugge R, Koops R, Hoekstra JBL, DeVries JH. Feasibility of a portable bihormonal closed-loop system to control glucose excursions at home under freeliving conditions for 48 hours. Diabetes Technol Ther 2014; 16: $131-36$

page $\mathrm{S}-93$

Waller D, Johnston C, Molyneaux L, Brown-Singh L, Hatherly $\mathrm{K}$, Smith L, Overland J. Glycemic control and blood glucose monitoring over time in a sample of young Australians with type 1 diabetes: the role of personality. Diabetes Care 2013; 36: $2968-73$

page $\mathrm{S}-7$

Weinstock RS, Trief PM, Cibula D, Morin PC, Delahanty LM. Weight loss success in metabolic syndrome by telephone interventions: results from the SHINE study. J Gen Intern Med 2013; 28: 1620-28

page $\mathrm{S}-59$

Wheeler BJ, Donaghue KC, Heels K, Ambler GR. Family perceptions of insulin pump adverse events in children and adolescents. Diabet Technol Ther 2014; 16: 204-7 pages S-24 and S-114

White WB, Cannon CP, Heller SR, Nissen SE, Bergenstal RM, Bakris GL, Perez AT, Fleck PR, Mehta CR, Kupfer S, Wilson C, Cushman WC, Zannad F; EXAMINE Investigators. Alogliptin after acute coronary syndrome in patients with type 2 diabetes. N Engl J Med 2013; 369: 1327-35 page $\mathrm{S}-120$

Wijsman CA, Westendorp RGJ, Verhagen EALM, Catt M, Slagboom PE, de Craen AJM, Broekhuizen K, van Mechelen W, van Heemst D, van der Ouderaa F, Mooijaart SP. Effects of a web-based intervention on physical activity and metabolism in older adults: randomized controlled trial. $\mathrm{J} \mathrm{Med}$ Internet Res 2013; 15: e233 page $\mathrm{S}-63$

Wojcik M, Zieleniak A, Mac-Marcjanek K, Wozniak LA, Cypryk K. The elevated gene expression level of the $A_{2 B}$ adenosine receptor is associated with hyperglycemia in women with gestational diabetes mellitus. Diabetes/Metab Res Rev 2014; 30; 42-53

page $\mathrm{S}-70$

Wysham C, Grimm M, Chen S. Once weekly exenatide: efficacy, tolerability, and place in therapy. Diabetes Obes Metab 2013; 15: 871-81

page $\mathrm{S}-123$
Zambrowicz B, Ding ZM, Ogbaa I, Frazier K, Banks P, Turnage A, Freiman J, Smith M, Ruff D, Sands A, Powell D. Effects of LX4211, a dual SGLT1/SGLT2 inhibitor, plus sitagliptin on postprandial active GLP-1 and glycemic control in type 2 diabetes. Clin Ther 2013; 35: 273-85.e7 page $\mathrm{S}-126$

Zambrowicz B, Ogbaa I, Frazier K, Banks P, Turnage A, Freiman J, Boehm KA, Ruff D, Powell D, Sands A. Effects of LX4211, a dual sodium-dependent glucose cotransporters 1 and 2 inhibitor, on postprandial glucose, insulin, glucagon-like peptide 1 , and peptide tyrosine in a dose-timing study in healthy subjects. Clin Ther 2013; 35: 1162-73.e8

page S-125

Zhang L, Wang L, Meng Z, Gan H, Gu R, Wu Z, Gao L, Zhu X, Sun W, Li J, Zheng Y, Dou G. A novel exendin-4 human serum albumin fusion protein, E2HSA, with an extended half-life and good glucoregulatory effect in healthy rhesus monkeys. Biochem Biophys Res Commun 2014; 445: 511-16 page $\mathrm{S}-123$

Zhang LN, Xu L, Zhou HY, Wu LY, Li YY, Pang T, Xia CM, Qiu BY, Gu M, Dong TC, Li JY, Shen JK, Li J. Novel smallmolecule AMP-activated protein kinase allosteric activator with beneficial effects in $\mathrm{db} / \mathrm{db}$ mice. PLoS One 2013; 8: e72092

page $\mathrm{S}-130$

Zhou J, Mo Y, Li H, Ran X, Yang W, Li Q, Peng Y, Li Y, Gao X, Luan X, Wang W, Xie Y, Jia W. Relationship between HbAlc and continuous glucose monitoring in Chinese population: a multicenter study. PLoS One 2013; 8: e83827 page $\mathrm{S}-19$

Zinman B, DeVries H, Bode B, Russell-Jones D, Leiter LA, Moses A, Johansen T, Ratner R on behalf of the NN1250-3724 (BEGIN:EASY AM) and NN1250-3718 (BEGIN:EASY PM) Trial Investigators. Efficacy and safety of insulin degludec three times a week versus insulin glargine once a day in insulin-naïve patients with type 2 diabetes: results of two phase 3, 26 week, randomized, open-label, treat-to-target, non-inferiority trials. Lancet Diabetes Endocrinol 2013; 1: 123-31

page $\mathrm{S}-41$

Zornoza-Moreno M, Fuentes-Hernández S, Prieto-Sánchez MT, Blanco JE², Pagán A, Rol M-Á, Parrilla JJ, Madrid JA, Sánchez-Solis M, Larqué E. Influence of gestational diabetes on circadian rhythms of children and their association with fetal adiposity. Diabetes/Metab Res Rev 2013; 29: 483-91

page $\mathrm{S}-74$ 